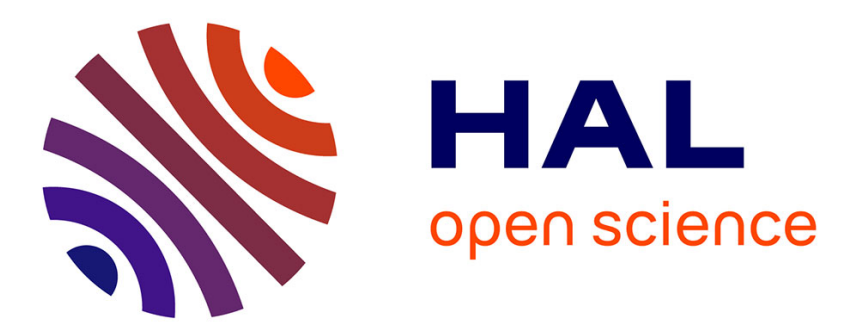

\title{
The Impact of Intergroup Emotions on Forgiveness in Northern Ireland
}

Tania Tam, Miles Hewstone, Ed Cairns, Nicole Tausch, Greg Maio, Jared Kenworthy

\section{- To cite this version:}

Tania Tam, Miles Hewstone, Ed Cairns, Nicole Tausch, Greg Maio, et al.. The Impact of Intergroup Emotions on Forgiveness in Northern Ireland. Group Processes and Intergroup Relations, 2007, 10 (1), pp.119-136. 10.1177/1368430207071345 . hal-00571643

\section{HAL Id: hal-00571643 https://hal.science/hal-00571643}

Submitted on 1 Mar 2011

HAL is a multi-disciplinary open access archive for the deposit and dissemination of scientific research documents, whether they are published or not. The documents may come from teaching and research institutions in France or abroad, or from public or private research centers.
L'archive ouverte pluridisciplinaire HAL, est destinée au dépôt et à la diffusion de documents scientifiques de niveau recherche, publiés ou non, émanant des établissements d'enseignement et de recherche français ou étrangers, des laboratoires publics ou privés. 


\title{
The Impact of Intergroup Emotions on Forgiveness in Northern Ireland
}

\author{
Tania Tam and Miles Hewstone \\ University of Oxford
}

Ed Cairns

University of Ulster

Nicole Tausch

University of Oxford

Greg Maio

Cardiff University

Jared Kenworthy

University of Texas at Arlington

\begin{abstract}
Although prejudice researchers have mainly focused their attention on changing attitudes toward outgroups, other outcome variables may also be important. In post-conflict reconciliation, intergroup forgiveness may play a crucial role in helping groups in conflict put the atrocities of the past behind them (Cairns, Tam, Hewstone, \& Niens, 2005). Two studies showed that both the specific intergroup emotion of anger and infrahumanization (the attribution of more human emotions to the ingroup than to the outgroup) predicted decreased intergroup forgiveness in Northern Ireland. Results further revealed intergroup contact as a potential means of reducing anger toward the outgroup and improving attitudes toward them. This research integrated prior interpersonal theory with intergroup literature to examine the concept of intergroup forgiveness and its predictors. Results are discussed in terms of their implications for reconciliation in conflict societies.
\end{abstract}

KEYWORDS forgiveness, infrahumanization, intergroup contact, intergroup emotions

The cycle of reprisal and counter-reprisal ... had to be broken, and [...] the only way to do this was to go beyond retributive justice to restorative justice, to move on to forgiveness, because without it there was no future. (Archbishop Desmond Tutu, No Future Without Forgiveness, p. 209)

\author{
Author's note \\ Address correspondence to Tania Tam, \\ Legal Services Research Centre, 85 Grays \\ Inn Road, London NW6 4PT, UK \\ [email: Tania.tam@legalservices.gov.uk]
}


To escape a self-perpetuating cycle of violence and retaliation inherent in situations of widespread sectarian conflict, violence on both sides must cease, and a strategy of cooperation must be pursued (McLernon, Cairns, \& Hewstone, 2002). Intergroup forgiveness may serve to break the cycle of violence and aid in the reconciliation process after a protracted intergroup conflict. An understanding of intergroup forgiveness is of particular importance in post-conflict societies such as Northern Ireland, where groups involved in intergroup conflict are often encouraged to 'move on' from the past. Where intergroup conflict is concerned, however, the past is intimately part of the present. The past forms part of the ongoing intergroup competition central to any intergroup conflict, with people in Northern Ireland remembering battles fought long ago (Cairns \& Darby, 1998).

The research on building forgiveness has centered on the individual and interpersonal levels (e.g. McCullough, Pargament, \& Thoresten, 2000). Although the findings of this research are relevant to the intergroup level, they are not immediately applicable to it. Therefore, relevant research on interpersonal forgiveness and the effects of forgiveness on individuals must be extrapolated and empirically examined on the intergroup level to elucidate why certain individuals on both sides of the divide are able to forgive past wrongs and break the cycles of revenge that typically escalate intergroup conflict. On November 8, 1987, for instance, when Gordon Wilson's daughter, Marie, was killed in an IRA bomb attack, he said, 'I bear no ill will, I bear no grudge'. On the other side of the sectarian divide, Michael McGoldrick's son, Michael, was shot by Protestant paramilitaries on July 8 , 1996 , yet he pleaded, 'Bury your pride with my boy. To those who've done this, I and my family forgive you' (Cairns et al., 2005). Such acts of forgiveness may break a cycle of vengeance and violence. Such acts are, however, rare.

Forgiveness permits the relationship between the conflicting parties to move forward after a transgression (Zechmeister \& Romero, 2002). Forgiving a transgressor has, in fact, repeatedly been shown to result in less turmoil and more positive emotional reactions compared with not forgiving a transgressor (McCullough, Bellah, Kilpatrick, \& Johnson, 2001). Thus, forgiveness may promote overall relationship satisfaction in interpersonal relations (Kachadourian, Fincham, \& Davila, 2005). On the intergroup level, forgiveness involves the release of negative feelings toward the perpetrator's group (Tutu, 1999) and prosocial behaviors toward that group (Wohl \& Branscombe, 2005). People who forgive a historical perpetrator category (e.g. Jews forgiving Germans) are, for example, more willing to become friends with a member of that group and to buy products made by them (e.g., German cars; Wohl \& Branscombe, 2005).

Negative emotions that result from intergroup conflict persist long after the violence itself has stopped (Wohl \& Branscombe, 2005). These negative cross-community feelings must be addressed in the promotion of more positive intergroup relations and reconciliation of the two communities. This survey explores intergroup emotions in the prediction of intergroup forgiveness in Northern Ireland, based on theories of both interpersonal forgiveness and intergroup relations.

\section{Intergroup emotions and forgiveness: the role of anger}

Relations between groups often involve intense emotions, and although social psychological explanations for discriminatory behavior tend to focus on prejudice as an attitude, specific intergroup emotions may be more conducive to predicting intergroup behaviors than general outgroup evaluation is (Smith, 1993). Differentiated emotions may be more accurate for predicting behavior than attitudes are, because evaluating groups as simply positive or negative does not allow for differential predictions about groups that are feared, hated, respected, or liked. Moreover, a greater variety of outgroup behaviors may be explained by various emotions (Mackie \& Smith, 2002). Anger, for example, is particularly related to decreased forgiveness. In fact, according to Baumeister, Exline, \& Sommer (1998), 'to forgive someone means to cease feeling angry or resentful over the transgression' (p. 85). The process of forgiving, 
on the individual level, involves letting go of negative emotions without seeking to improve relations with the transgressor (Baumeister et al., 1998). However, whether or not the victim seeks to improve relations with the transgressor, forgiveness can occur only after emotions aroused by offensive behavior have been addressed (Harber \& Wenberg, 2005).

In forgiveness intervention programs, there is also a need to confront angry emotions after being hurt. For example, although Enright and colleagues' 'Process Model of Forgiveness' emphasizes cognitive processes such as reframing the offense, achieving insight, and finding meaning, it begins with the 'confrontation of anger' (Enright \& Coyle, 1998). According to Freedman and Enright (1996), confronting hostile emotions comes before the cognitive shifts that solidify forgiveness: 'Before forgiving, one needs to express his or her justified anger' (p. 985) and 'the point is to release, not harbor, the anger' (p. 986). The confrontation and expression of offense-related emotions is one of the most important elements in the 'Process Model of Forgiveness' (Enright \& Coyle, 1998).

Baumeister and colleagues (1998) explicitly define forgiveness as an emotional state. Research indeed suggests that forgiveness is rooted in emotions (e.g. Harber \& Wenberg, 2005) and therefore should be constrained by the laws that govern emotions. One principle of emotions is that they are involuntary, in the sense that, once aroused, emotions cannot be defused at will (Zajonc, 1980). Thus, although a person may want to stop feeling angry, hostile, or resentful, directly trying to expunge these feelings may not be sufficient to stop them. In fact, efforts to consciously suppress or deny these emotions are more likely to increase rather than decrease their influence (Wegner \& Wenzlaff, 1996). Interventions are needed to deal with intergroup emotions themselves. Thus it is important to establish predictors of intergroup emotions. One such predictor is intergroup contact, which has been shown not only to promote positive intergroup emotions but also to mitigate negative ones (Miller, Smith, \& Mackie, 2004).
Specific emotions are states of immediate readiness to act (Frijda, 1986) and are theorized as directing behavior (Smith, 1993). Mackie, Devos, and Smith (2000) have shown that although anger and fear are both forms of negative affect, they are empirically distinct and provoke different intergroup behaviors: fear predicts avoidant action tendencies, while anger predicts aggressive action tendencies against the outgroup (Devos, Silver, Mackie, \& Smith, 2002). In addition to these negative intergroup emotions, our recent studies have shown positive intergroup emotions to be key predictors of out-group attitudes and action tendencies (Tam et al., 2006). In the case of predicting forgiveness toward the outgroup, the specific emotion of anger is likely to be involved. We thus tested this for the first time on the intergroup level, and hypothesized that the specific intergroup emotion of anger would be a better predictor of decreased intergroup forgiveness than a general outgroup evaluation and other specific intergroup emotions would be.

\section{Infrahumanization and forgiveness}

Wohl and Brancombe (2005) maintain that the resolution of social conflict involves more than just changing negative beliefs; it is also necessary to see the humanity in the other. Their research demonstrated that perpetrator groups that are seen as 'human' elicit intergroup forgiveness and more positive intergroup behaviors toward the outgroup (i.e. increased willingness to befriend outgroup members and buy outgroup products). The Truth and Reconciliation Commission in South Africa has similarly shown us that what seems to be needed is an ability to see outgroup members as human like the self (Tutu, 1999). Such perceptions of the 'human family' may well be crucial for intergroup forgiveness and the creation of a more harmonious future (Wohl \& Brancombe, 2005). We thus investigated the relationship between infra-humanization (seeing the outgroup as less human than the ingroup) and reduced intergroup forgiveness. Intergroup behavior may be a result not only of emotions felt toward the outgroup, but also of differential 
emotions attributed to the outgroup, i.e. fewer 'human' emotions attributed to the outgroup vs. the ingroup. Research has shown that people tend to infuse an essence (biological, cultural, religious, etc.) into social groups in order to explain their differences. Thus, an ingroup perceived as superior may be endowed with 'the' human essence, while outgroups are seen as 'infra-humans' (Leyens et al., 2001).

Leyens and colleagues (2001) have demonstrated this 'infrahumanization' process in multiple groups with a history of mild conflict (e.g. Flemish-speaking vs. French-speaking Belgians). They have shown that people perceive what emotion researchers (e.g. Ekman, 1992) call secondary emotions (e.g. nostalgia) as more unique to humans than primary emotions (e.g. pleasure), which may also be attributed to animals. Researchers generally agree that emotions such as anger, fear, and joy are common to both animals and humans, while emotions such as guilt, melancholy, and embarrassment are unique to human beings (Ekman, 1992). People tend to attribute secondary (human) emotions more to the ingroup than to the outgroup (Leyens et al., 2000). This infrahumanization has even been demonstrated on the implicit level (Paladino et al., 2002). Using the Implicit Association Test (Greenwald, McGhee, \& Schwartz, 1998), Paladino and colleagues (2002) showed that participants implicitly associated secondary emotions with the ingroup and primary emotions with the outgroup more than the other way around.

In this study, we aimed to investigate Leyens and colleagues' concept of infrahumanization in an area with a history of extreme conflict. We thus examined the differential attribution of secondary and primary emotions to the ingroup vs. the outgroup in Northern Ireland, and hypothesized that those who infra-humanized the outgroup less would be more willing to forgive them. As Tutu (1999) and Wohl and Branscombe (2005) suggest, forgiveness may be a particularly ‘human' act.

Extensive evidence has established that positive interaction between members of different groups can reduce intergroup prejudice and hostility (Allport, 1954; Pettigrew \& Tropp, 2006). Intergroup contact has in fact long been considered one of psychology's most effective strategies for improving intergroup relations (Dovidio, Gaertner, \& Kawakami, 2003). In this study, we examined potential differential outcomes that intergroup contact may have for intergroup relations in Northern Ireland.

Paolini, Hewstone, Cairns, and Voci (2004) have shown that anxiety mediates the effects of contact on prejudice in Northern Ireland. Our previous research has revealed that it is not only anxiety but also other intergroup emotions (i.e. anger-related emotions and positive emotions) that explain the effects of contact on prejudice (Tam et al., 2006). Emotional processes of healing are crucial to post-conflict reconciliation (Nadler, 2001), and anger is a particularly relevant emotion associated with forgiveness (McCullough et al., 2000). We therefore examined the impact of contact on specific intergroup emotions, such as anger, fear, and positive emotions, and hypothesized that people who experienced anger toward the outgroup would be particularly disinclined to forgive them, even after controlling for people's general evaluation of the outgroup. We hypothesize moreover that specific intergroup emotions such as anger will be more predictive of outcome variables such as intergroup forgiveness than will a general evaluation such as general attitude toward the outgroup.

\section{The current research}

The current research investigates the predictors of intergroup forgiveness in Northern Ireland. It is crucial to investigate forgiveness and reconciliation in real conflict situations, as laboratory research cannot take into account contextual variables vital to intergroup relations in conflict areas (Pettigrew, 1997). Since 1969, over 3,600 people have been killed in sectarian violence in Northern Ireland, and more than half the Northern Irish population knows someone who was injured or killed in 'The Troubles' (Smyth \& Hamilton, 2003). Many people in Northern Ireland, especially the Protestant community, believe it should remain part of the United Kingdom. Others, particularly the Catholic community, take the opposite perspective and believe it should instead become part of the 
Republic of Ireland. Religious polarization in Northern Ireland is so strong that vital aspects of life (e.g. areas of residence, schools, shops, political parties, sports, first and last names) can be identified as being either Catholic or Protestant (see Hargie \& Dickinson, 2003).

Despite resolution of a range of economic and social issues (such as differential employment, education, and housing for Catholics and Protestants), division is still highly symbolic and psychologically real, and the conflict pervades people's everyday lives. In a post-conflict society, it is imperative to promote intergroup harmony, but the question remains, how can this best be done? In this study, we address the mechanisms underlying intergroup forgiveness in Northern Ireland.

\section{Intergroup forgiveness in the context of Northern Ireland}

To elucidate the concept of intergroup forgiveness in Northern Ireland, McLernon, Cairns, Hewstone, and Smith (2002) conducted a series of focus groups with people from organizations devoted to the reduction of conflicts, exparamilitary group members, and victims themselves. Most participants agreed that it was easier to forgive an individual than a group, because it was easier to trust an individual than each member of the other community. Victims were hostile to the idea of forgiveness and viewed forgiveness as an act that justified the wrongs done to them. Ex-members of paramilitary groups were similarly hostile; they felt their acts were justified at the time and that they did not need to ask for, or offer, forgiveness. All groups stressed that attempting to impose intergroup forgiveness was likely to be counterproductive, but that an act of remembrance such as a monument might give people the opportunity to share the loss and make forgiving easier.

We used a measure of intergroup forgiveness in Northern Ireland that was developed from these focus groups (see McLernon et al., 2002) to investigate the concept of intergroup forgiveness and assess psychological processes that may foster or inhibit forgiveness in Northern Ireland. We explored the predictors of intergroup forgiveness in Northern Ireland, basing our conceptualization of intergroup forgiveness on the results of focus groups as well as on previous research and theorizing on interpersonal forgiveness, intergroup relations, and emotion, and the small literature on intergroup forgiveness in this context (Hewstone et al., 2004; Hewstone, Cairns, Voci, Hamberger, \& Niens, 2006), which suggests segregation in Northern Ireland to hinder intergroup forgiveness.

On this basis, we hypothesized that: (1) angerrelated intergroup emotions would be particularly associated with decreased intergroup forgiveness; and (2) infra-humanization would also be associated with decreased intergroup forgiveness. We hypothesized a model in which intergroup contact would be associated with decreased anger and infra-humanization, which would in turn lead to increased intergroup forgiveness. This model is depicted in Figure 1. Anger, infrahumanization, and attitudes were examined at the same level, as no causal order among them was hypothesized. The plus signs indicated a hypothesized positive relation between variables, and the minus signs indicated a hypothesized negative relation between variables.

\section{Study 1}

\section{Method}

Participants and procedure Participants were 97 students from three universities in Northern Ireland. Thirty-six participants identified themselves as Protestant; sixty-one identified themselves as Catholic. Seventy-five participants were female, 18 were male, and 4 did not report their sex; their mean age was 23 years $(S D=6.3)$. Participants were asked to complete a questionnaire about social attitudes and intergroup relations.

\section{Measures}

Intergroup forgiveness The measure of intergroup forgiveness was a shortened form of one used in previous research (Hewstone et al., 2004, 2006), developed through a series of focus groups with Northern Irish citizens (see McLernon et al., 2002). Participants were given the instructions: 'You may have read in the newspapers, or 


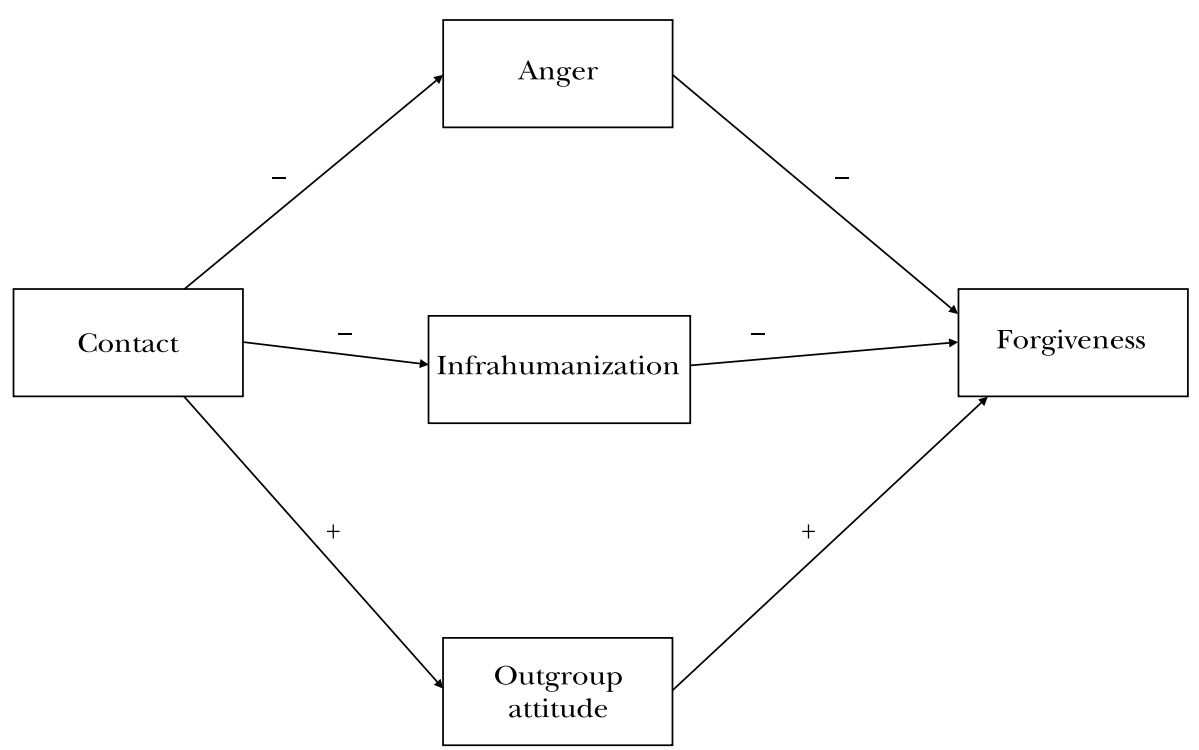

Figure 1. Hypothesized model. The plus signs indicate a hypothesized positive relation between variables, and the minus signs indicate a hypothesized negative relation between variables.

heard/seen discussions on the radio and TV about reconciliation and forgiveness in Northern Ireland. Now, please tell us how you feel about these issues'. Participants rated four items on 4 -point scales ( 1 = Disagree strongly, $4=$ Agree strongly): 'Only when the two communities of Northern Ireland learn to forgive each other can we be free of political violence', 'My community should, as a group, seek forgiveness from the other community for past paramilitary activities', 'Northern Ireland will never move from the past to the future, until the two communities learn to forget about the past', and 'Northern Ireland will never move from the past to the future, until the two communities learn to draw a line under the past'. Cronbach's alpha for these four items was .69 .

Intergroup emotions Mackie et al.'s (2000) scale was adapted to assess negative (angry and fearful) intergroup emotions in Northern Ireland, and a set of positive emotions was added to this scale. Participants were asked to rate how much of each emotion (angry, hatred, furious, irritated, nervous, anxious, fearful, worried, afraid, cheerful, happy, pleasant) they felt when thinking about members of the other community on 7 -point scales $(0=$ Not at all, $6=$ Extremely). These emotions were presented in a randomized order.

To examine the structure of emotional reactions to the outgroup, we conducted factor analyses. First, a principal components analysis on the 12 emotion items, retaining eigenvalues greater than 1, revealed three factors that accounted for $76.8 \%$ of the variance. Factor loadings, after varimax rotation, showed that all the anger items (angry, hatred, furious, irritated) loaded onto the first factor $(>.69)$, all the fear items (nervous, anxious, fearful, worried, afraid) loaded onto the second factor $(>.80)$, and all the positive emotion items (cheerful, happy, pleasant) loaded onto the third factor (>.81), suggesting that anger, fear, and positive emotions were clearly distinct intergroup emotions. Cronbach's alpha for the four anger-related items was .89. For the five fear-related items, it was .93 , and for the three happy-related items, it was .82 .

Infrahumanization The measure of infrahumanization developed by Leyens and colleagues 
(2001) was adapted for the Northern Irish context and assessed the differential attribution of primary (universal) and secondary (uniquely human) emotions to the outgroup vs. the ingroup with two checklists. Participants were asked to mark the words which they believed to be typical of the other community (outgroup) in one list and to mark the words which they believed to be typical of their own community (ingroup) in the other list. The lists consisted of seven positive primary emotions (surprise, calmness, attraction, enjoyment, caring, excitement, pleasure), seven positive secondary emotions (optimism, love, passion, elation, nostalgia, admiration, hope), seven negative primary emotions (pain, fear, anger, fury, panic, fright, suffering), and seven negative secondary emotions (humiliation, shame, guilt, disgust, melancholy, disconsolate, disenchantment). As in previous research, participants were asked to select as many traits as they liked but were encouraged to choose traits sparingly and to limit their choices to descriptors they believed to be especially relevant to their or the other community.

Outgroup attitudes Attitudes toward the other community were assessed using a modified version of Wright, Aron, McLaughlin-Volpe, \& Ropp's (1997) 'General Evaluation Scale'. Participants were asked to evaluate the other community on 5-point semantic differential scales (1-5): warm-cold (reverse-coded), negative-positive, friendly-hostile (reverse-coded), generousselfish (reverse-coded), insensitive-sensitive, and insincere-sincere. The six items created a reliable index reflecting attitudes toward the other community. Cronbach's alpha for these six items was .82.

Intergroup contact Contact quantity was assessed by asking participants, 'How much contact do you have with people who are of a different religion to you/from the other community in just chatting to people?' on a 7-point scale $(0=$ None at all, $6=$ A great deal $)$. Contact quality was assessed by asking participants, 'In general, when you meet people of a different religion/from the other community, do you find the contact pleasant or unpleasant?' on a 7-point scale $(0=$ Very unpleasant, $6=$ Very pleasant $)$. To measure the amount of high quality contact, the interaction between quantity and quality of contact was examined, by multiplying quantity and quality of contact together. This procedure, adopted by previous researchers (e.g. Voci \& Hewstone, 2003), allows us to consider these two aspects of contact simultaneously. In fact, quantity or quality of contact taken separately are often not enough to reduce prejudice; an optimal combination of the two is needed (Allport, 1954).

\section{Results and discussion}

We hypothesized that anger and infrahumanization would be associated with decreased intergroup forgiveness. To assess infrahumanization, we computed composite scores for the number of primary and secondary emotions attributed to the ingroup and outgroup for each participant by combining the selected emotions. To control for the number of emotions selected in general, proportion scores were calculated such that each composite score was divided by the total number of emotions selected. We then calculated a final infrahumanization score by subtracting the proportion score for secondary emotions attributed to the ingroup from the proportion score for secondary emotions attributed to the outgroup. The difference between the proportion score of primary emotions attributed to the outgroup and the proportion score of primary emotions attributed to the ingroup was also computed. We similarly examined the differential valence of emotions attributed to the ingroup vs. the outgroup, and calculated the proportion of positive and negative emotions attributed to ingroup vs. the outgroup.

To investigate the hypothesized predictors of intergroup forgiveness, regression analyses were conducted, and forgiveness was regressed onto quality of contact, quantity of contact, and their cross-product, anger, fear, and positive intergroup emotions, outgroup attitude, infra-humanization, the differential attribution of primary emotions to the ingroup vs. the outgroup, and the differential attribution of positive and negative emotions to the ingroup vs. the outgroup 
(to account for valence) simultaneously. As predicted, anger and intra-humanization predicted reduced forgiveness $(\beta=-.40, p<.01$ and $\beta=-.26, p<.05$, respectively), over and above the effects of quality of contact ( $\beta=-.15$, $n s)$, quantity of contact $(\beta=-.16, n s)$, quality $\times$ quantity $(\beta=.18, n s)$, fear $(\beta=.23, p<.05)$, positive emotions $(\beta=.03, n s)$, outgroup attitude $(\beta=.20, p<.05)$, the differential attribution of primary emotions to the ingroup vs. the outgroup $(\beta=.07, n s)$, and the differential attribution of positive and negative emotions to the ingroup vs. the outgroup ( $\beta=.08$ and $\beta=-.17$, respectively, both $n s$ ).

We then evaluated the proposed model with only the hypothesized (manifest) variables (see Figure 1) using structural equation modeling (AMOS 5.0; Arbuckle, 2004). Covariance matrices were used as input (see Table 1), and estimates were derived using the maximum likelihood procedure. To assess overall model fit, we used the chi-square test, the comparative fit index (CFI), the root mean square of approximation (RMSEA), and the standardized root mean square residual (SRMR). A satisfactory fit is generally indicated by a $\chi^{2} / d f$ ratio $\leq 3$, a CFI $\geq .95$, an RMSEA $\leq .08$, and an SRMR $\leq .08$ (Voci \& Hewstone, 2003).

The structural equation model examined intergroup contact as a potential predictor of anger-related emotions, infrahumanization, and outgroup attitudes, which in turn predicted intergroup forgiveness. Intergroup contact was assessed as the cross-product of quantity and quality of contact, as in previous research (e.g. Voci \& Hewstone, 2003).The fit of the model was $\operatorname{good}\left(\chi^{2}=.02, d f=1, p=.88, \chi^{2}\right)$ $d f=.024, \mathrm{CFI}=1.00, \mathrm{RMSEA}=.00, \mathrm{SRMR}=.00$ ). As expected, the model showed that anger, infrahumanization, and outgroup attitudes were significant predictors of intergroup forgiveness in the model $(\beta=-.27, \beta=-.21$, and $\beta=.21$, all $p<.05)$. Moreover, intergroup contact predicted reduced anger and more positive outgroup attitudes, and marginally predicted reduced infrahumanization. Twenty-three per cent of the variance in forgiveness was explained in the model (see Figure 2).

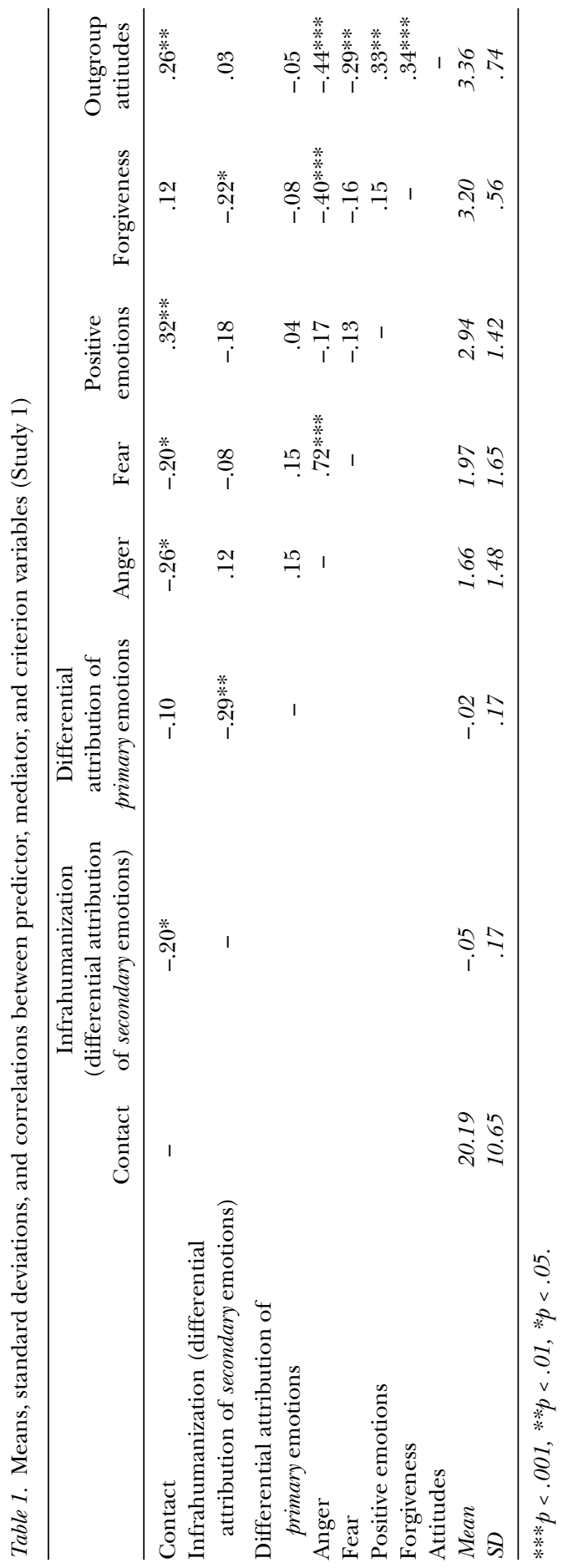


Alternative models Although the hypothesized model fits the data well, there are always alternatives (MacCullem \& Austin, 2000), especially for a relatively new area of investigation such as that of intergroup forgiveness. We thus considered two options. In the first alternative model, we tested the potential for forgiveness to mediate the effects of the originally hypothesized mediators on promoting intergroup contact. The model thus included decreased anger, decreased infrahumanization, and more positive attitudes as predictors of greater intergroup forgiveness, which then predicted higher levels of positive contact. The second alternative model tested the possibility that forgiveness mediates the effects of contact on the originally hypothesized mediators. In other words, contact leads to greater intergroup forgiving, which then leads to decreased anger, decreased infrahumanization, and more positive attitudes. The two alternative models are statistically equivalent, as they are the reverse causal models of one another. These alternative models did not fit the data better than the proposed model did $\left(\chi^{2}(3)=10.14\right.$, $p=.02 ;$ RMSEA $=.15$; SRMR $=.08$; CFI $=.87$ ). In fact, they fit the data significantly worse than the proposed model did $\left(\Delta \chi^{2}=10.12, \Delta d f=2\right.$, $p<.05$.

Lastly, we hypothesized that the relationship between the specific intergroup emotion of anger and intergroup forgiveness would be stronger than the relationship between general evaluation (outgroup attitude) and forgiveness. Although the effect of anger on forgiveness was more highly significant than the effect of outgroup attitudes on forgiveness, we conducted a structural equation model with equality constraints imposed to statistically compare their effects and confirm that this difference was significant. Equality constraints were placed on the paths from anger to forgiveness and from attitudes to forgiveness. The fit of this model was significantly worse than the fit of the original model in which coefficients were freely estimated (unconstrained) $\left(\chi^{2}(2)=15.70\right.$, $p<.001 ; \mathrm{RMSEA}=.25 ; \mathrm{SRMR}=.10 ; \mathrm{CFI}=.76)$.

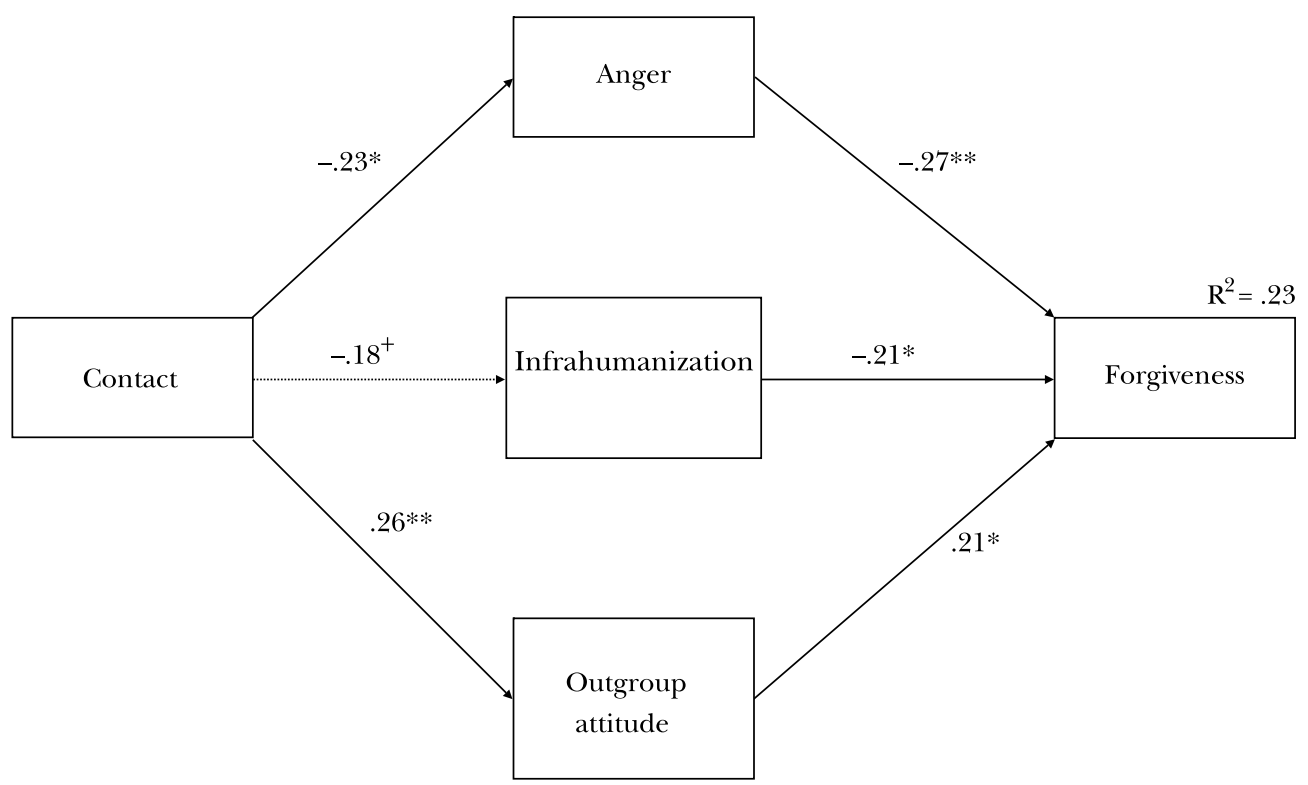

Figure 2. Structural equation model of distal and proximal predictors of forgiveness toward the other community for Study 1. Standardized coefficients.

$+p=.06 ; * p<.05 ; * * p<.01 ; * * * p<.001 ; N=97$. 
The difference in $\chi^{2}$ was $15.68, \Delta d f=1, p<.05$, indicating that anger predicted significantly more variance in intergroup forgiveness than did attitudes.

The results of Study 1 confirmed the hypotheses. As predicted, both anger and infrahumanization predicted reduced forgiveness, over and above the effects of the other variables. That is, controlling for the effects of other intergroup emotions, contact, outgroup attitudes, and the differential attribution of primary, positive, and negative emotions to the ingroup vs. the outgroup shows the importance of anger and the differential attribution of secondary, rather than primary or valenced emotions, for predicting decreased forgiveness. Moreover, our hypothesized model of the predictors of intergroup forgiveness was confirmed. However, because of the small size of our sample, we sought to replicate the findings in a second study. It might also be argued, given the exact wording of the four items used in this study, that our measure of intergroup forgiveness, in fact, reflected respondents' attitudes toward forgiveness, rather than their actual forgiveness toward the outgroup. We therefore sought to improve this measure in our second study. We included all 10 items from the original 'Intergroup Forgiveness Scale for Northern Ireland' (Hewstone et al., 2004, 2006) and we added nine new items tailored to reflect definitions of forgiveness from the literature, i.e. in terms of a decreasing motivation to enact retribution and revenge (McCullough, Worthington, \& Rachal, 1997), letting go of negative affect in response to considerable injustice (Rye and Pargament, 2002), and abandoning the right to resentment and retaliation, and instead offering mercy to the offending party (Enright and Coyle, 1998).

\section{Study 2}

\section{Method}

Participants and procedure Participants were 101 students from a large university in Northern Ireland. Thirty-eight participants identified themselves as Protestant; 60 identified themselves as Catholic, and three identified themselves as other. These three were removed from further analyses. Forty-eight participants were female, 44 were male, and 6 did not report their sex; their mean age was 22 years $(S D=3.8)$. As in Study 1, participants were asked to complete a questionnaire about social attitudes and intergroup relations.

\section{Measures}

Intergroup forgiveness The new measure of intergroup forgiveness comprised 19 items, the four used in Study 1 and the following (each of which participants were asked to rate on 4-point scales, 1 = Disagree strongly, $4=$ Agree strongly): 'It is important that my community never forgets the wrongs done to us by the other community' (reverse-coded); 'It is important that my community never forgives the wrongs done to us by the other community' (reversecoded); 'My community has remained strong precisely because it has never forgiven past wrongs committed by the other community' (reverse-coded); 'I forgive the other community for past paramilitary activities'; 'I will never forgive past wrongs committed by the other community' (reverse-coded); 'It is important that we release our negative feelings toward the other community'; 'It is important that we abandon our right to resentment and retaliation'; 'I believe we should be merciful toward offenders from the other community'; 'I am able to view offenders from the other community with compassion'; 'I am able to let go of the negative emotions I have felt toward members of the other community who have acted unjustly to my community'; 'I believe revenge should be sought for acts committed by members of the other community' (reversecoded); 'We should forgive members of the other community for their past misdeeds'; 'We should never forgive members of the other community for past wrongs' (reverse-coded); 'The two communities in Northern Ireland must learn not to retaliate against political violence'; and 'People in my community think it is important to take revenge for all atrocities committed by the other community' (reverse-coded). Cronbach's alpha for the full scale was .89 .

Intergroup emotions Intergroup emotions were assessed with the same scale as in Study 1. The 
principal components analysis on the 12 items, retaining eigenvalues greater than 1 , again revealed three factors that accounted for $78.1 \%$ of the variance. Factor loadings, after varimax rotation, as in Study 1, showed that all the anger items (angry, hatred, furious, irritated) loaded onto the first factor $(>.72)$, all the fear items (nervous, anxious, fearful, worried, afraid) loaded onto the second factor (> .67), and all the positive emotion items (cheerful, happy, pleasant) loaded onto the third factor (> .78). Cronbach's alpha for the four anger-related items was .92; for the five fear-related items, it was .91; and for the three happy-related items, it was .86 .

Infrahumanization The measure of infrahumanization was the same as in Study 1.

Outgroup attitudes Attitudes toward the other community were assessed using a slightly different version of Wright et al.'s (1997) 'General Evaluation Scale'. Participants were asked to evaluate the other community on 5-point semantic differential scales (1-5): warm-cold (reverse-coded), negative-positive, friendly-hostile (reverse-coded), suspicioustrusting, respect-contempt (reverse-coded), and admiration-disgust (reverse-coded). The six items created a reliable index reflecting attitude towards the other community. Cronbach's alpha for these six items was .86.

Intergroup contact Intergroup contact was assessed in the same way as in Study 1. Again, to measure the amount of high quality contact, the quantity and quality of contact were multiplied together (see Voci \& Hewstone, 2003).

\section{Results and discussion}

As in Study 1, to investigate the hypothesized predictors of intergroup forgiveness, regression analyses were conducted, and forgiveness was regressed onto quality of contact, quantity of contact, and their cross-product, anger, fear, and positive intergroup emotions, outgroup attitude, infrahumanization, the differential attribution of primary emotions to the ingroup vs. the outgroup, and the differential attribution of positive and negative emotions to the ingroup vs. the outgroup. As predicted, anger and infrahumanization predicted reduced forgiveness $(\beta=-.59, p<.001$ and $\beta=-.25$, $p<.01$, respectively), over and above the effects of quality of contact $(\beta=.38, n s)$, quantity of contact $(\beta=.04, n s)$, quality $\times$ quantity $(\beta=$ $-.39, n s)$, fear $(\beta=.23, p<.06)$, positive emotions $(\beta=.07, n s)$, outgroup attitude $(\beta=.11, n s)$, the differential attribution of primary emotions to the ingroup vs. the outgroup $(\beta=.18, n s)$, and the differential attribution of positive and negative emotions to the ingroup vs. the outgroup $(\beta=.00$ and $\beta=-.26$, respectively, both $n s)$ (see Table 2).

We then evaluated the proposed model with only the relevant (manifest) variables (see Figure 1) using structural equation modeling (AMOS 5.0; Arbuckle, 2004). The structural equation model examined intergroup contact, as the cross-product of quantity and quality of contact, as a potential predictor of anger-related emotions, infrahumanization, and outgroup attitudes, which in turn predicted intergroup forgiveness. The fit of the model was good $\left(\chi^{2}=.01, d f=1, p=.91, \chi^{2} / d f=.01, \mathrm{CFI}=1.00\right.$, RMSEA $=.00$, SRMR $=.00)$. As expected, the model showed that anger, infrahumanization, and outgroup attitude were significant predictors of intergroup forgiveness in the model $(\beta=-.53$, $\beta=-.19$, and $\beta=.19$, all $p<.05)$. Intergroup contact predicted reduced anger toward the outgroup $(\beta=-.49, p<.001)$ and more positive outgroup attitudes $(\beta=.53, p<.001)$; however, contact did not predict reduced infrahumanization $(\beta=.10, n s)$. Fortyfour per cent of the variance in forgiveness was explained by our model (see Figure 3).

Alternative models We again considered two alternatives to the model proposed. The first alternative model again included decreased anger, decreased infrahumanization, and more positive attitudes as predictors of greater intergroup forgiveness, which then predicted higher levels of positive contact. The second alternative model tested the possibility that contact leads to greater intergroup forgiving, which then leads to decreased anger, decreased infrahumanization, and more positive attitudes. The alternative models did not fit the data better than the proposed model did $\left(\chi^{2}(3)=27.22\right.$, 


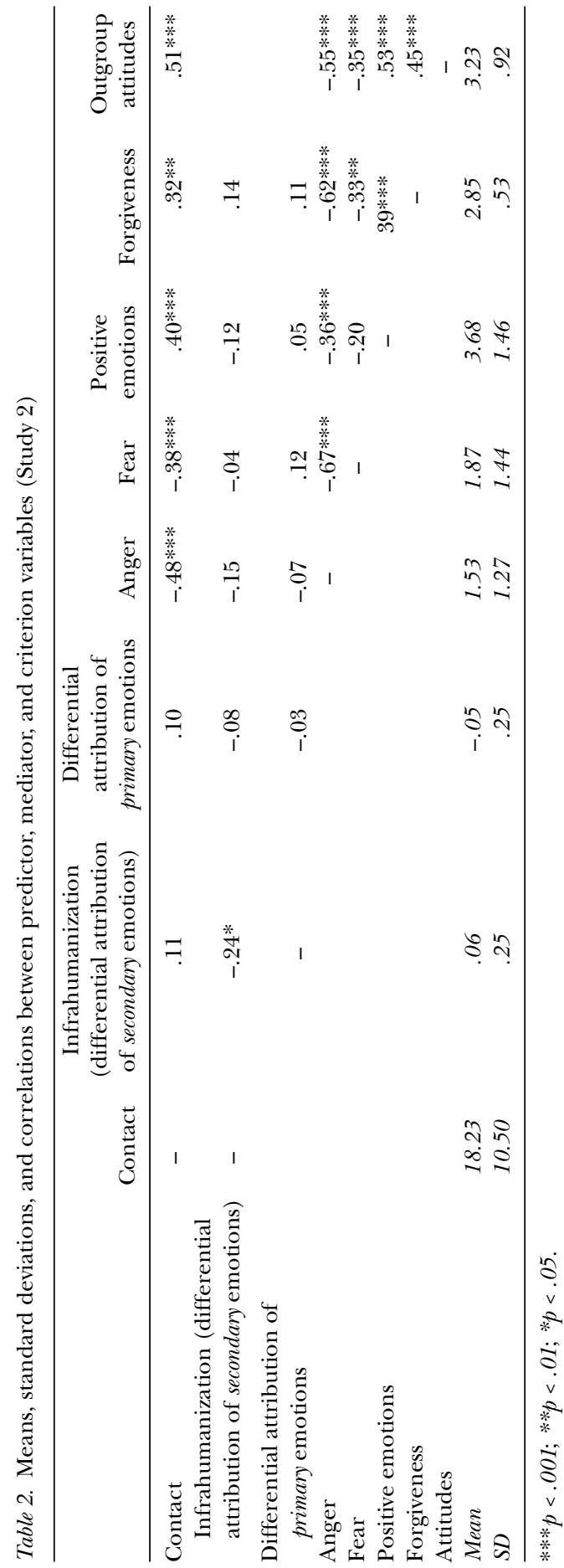

$p<.001 ;$ RMSEA $=.29 ;$ SRMR $=.08 ; \mathrm{CFI}=.79)$. As in Study 1, these two alternative models are statistically equivalent, as they are the reverse causal models of one another, and again both alternative models fit the data significantly worse than the proposed model did $(\Delta \chi 2=27.21$, $\Delta d f=2, p<.05$.

Finally, we again hypothesized that the relationship between the specific intergroup emotion of anger and intergroup forgiveness would be stronger than the relationship between a general evaluation (outgroup attitude) and forgiveness. Although the effect of anger on forgiveness was more highly significant in the model than the effect of outgroup attitudes on forgiveness, we conducted a structural equation model with equality constraints imposed to compare their effects statistically and confirm that this difference was significant. Equality constraints were placed on the paths from anger to forgiveness and from attitudes to forgiveness. The fit of this model was significantly worse than the fit of the original model in which coefficients were freely estimated (unconstrained) $(\chi 2(2)=45.52, p<.001$; RMSEA $=.46$; SRMR $=.19$; CFI $=.65)$. The difference in $\chi^{2}$ was $45.51, \Delta d f=1, p<.05$, indicating that anger predicted significantly more variance in intergroup forgiveness than did attitudes.

\section{General discussion}

Both Catholics and Protestants have experienced a history of murder and violence from the other community (Smyth \& Hamilton, 2003). Although the Belfast Agreement (signed on April 10, 1998) provided a way forward from 'The Troubles' (setting up a local assembly and a power-sharing government, embracing all the major political parties), the formal resolution of a conflict is often only the first step toward peaceful coexistence. Individuals within and beyond the parties involved must then engage in psychological processes to overcome their blighted history and engage in reconciliation (see Hewstone et al., in press). Forgiveness plays a key role in helping groups in conflict put the atrocities of the past behind them (Cairns et al., 2005). 


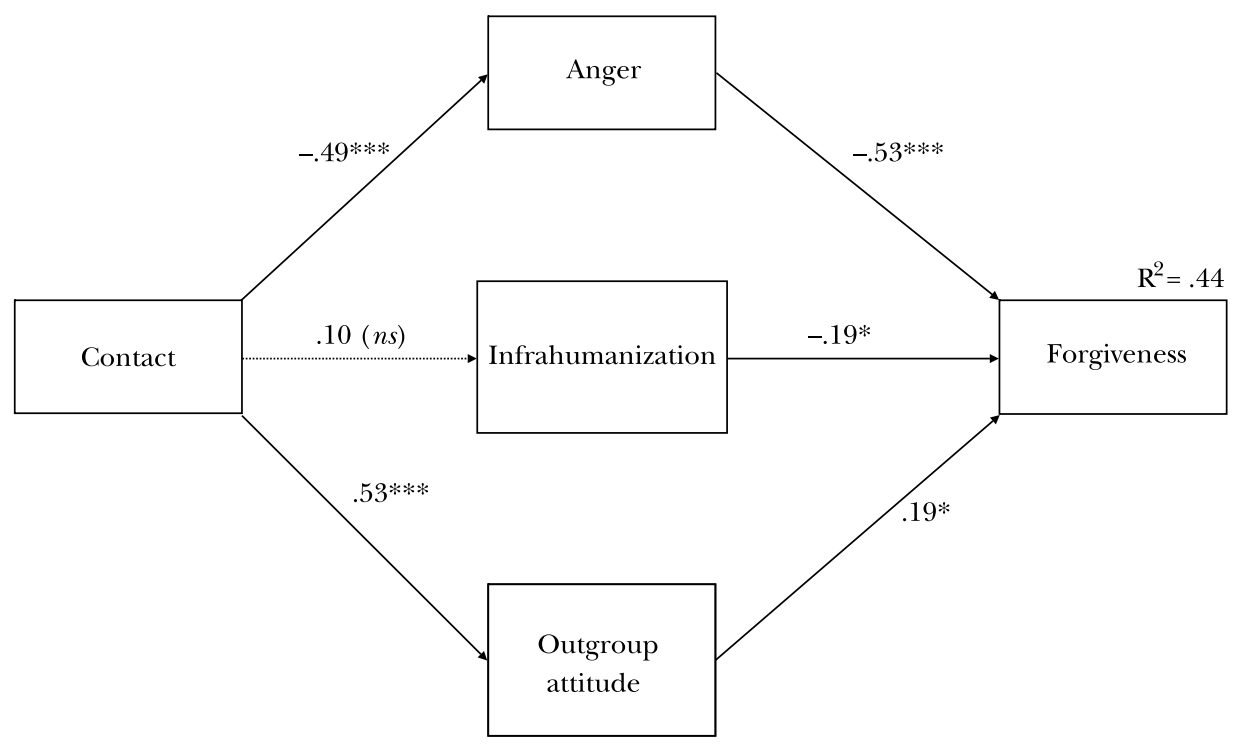

Figure 3. Structural equation model of distal and proximal predictors of forgiveness toward the other community for Study 2. Standardized coefficients.

$* p<.05 ; * * p<.01 ; * * * p<.001 ; N=101$.

To explore forgiveness at the community level rather than at the individual level, we used a measure of intergroup forgiveness that examined factors beyond personalized trauma on the individual level. This measure was designed from focus groups which specifically aimed to understand the concept of intergroup forgiveness in the context of Northern Ireland (McLernon et al., 2002). Based on the results of the focus groups as well as on previous theory and research on forgiveness and intergroup relations, key predictors of intergroup forgiveness were hypothesized and tested. Anger and infrahumanization were identified as proximal predictors of intergroup forgiveness, even after the effects of outgroup attitude, other emotions, and other variables were controlled for.

In this article, we provided two empirical examinations of the predictors of forgiveness in a real post-conflict area. These two studies not only elucidated mechanisms which hinder forgiveness toward the outgroup-namely anger toward and infrahumanization of the other community-but they also demonstrated the potential for frequent positive intergroup contact to mitigate that anger toward the outgroup and improve outgroup attitudes, and thereby increase the likelihood of forgiveness. Study 1 showed that intergroup contact was marginally predictive of reduced infrahumanization; however, Study 2 did not confirm this finding. Thus, although results showed that infrahumanization is detrimental to the process of forgiving the outgroup for past wrongs, contact may not necessarily ameliorate this infrahumanization.

Although fear and anger were significantly correlated, both being negative affect, they were distinctly separate emotions which differentially predicted forgiveness. While anger predicted reduced forgiveness, interestingly fear predicted increased outgroup forgiveness in both studies, although this effect was only marginal in Study $2(p<.06)$. (We believe, from focus groups and other research we have conducted, that fear relates to 'The Troubles' erupting again, and the understanding that mutual forgiveness must be a key part of the process of reconciliation needed to avoid that.) Positive emotions toward the outgroup did not relate to forgiveness. That is, it is not necessary for people to feel good 
about the other community to forgive them. But people who feel angry will not forgive. These results are consistent with previous research on interpersonal forgiveness, which demonstrates a strong link between feelings of anger toward a transgressor and lack of forgiveness. Anger impedes forgiveness (Worthington, 1998). To achieve intergroup forgiveness, it is also vital for group members to see the humanity in the other. Results supported this hypothesis and demonstrated the inverse relationship between infrahumanization and forgiveness. That is, people who infrahumanized the outgroup (and saw them as less human) tended to be less forgiving of the outgroup for past wrongs committed. Intergroup forgiving may thus be a result not only of reduced anger felt toward the outgroup, but also of an increased perception of the outgroup's humanity. Confirming our hypothesis, the differential attribution of secondary emotions to the ingroup over the outgroup (infrahumanization) was negatively related to intergroup forgiveness, over and above the differential attribution of primary (and positive and negative) emotions to the ingroup vs. the outgroup. The results thus demonstrated predictive validity for the infrahumanization measure in Northern Ireland and were in line with the hypothesis and previous research in other parts of the world.

Smith's (1993) intergroup emotions theory shifted the field of intergroup relations away from the traditional notion of prejudice as outgroup attitude to the conceptualization of prejudice as emotion. We explored this distinction empirically and predicted that the relationship between specific intergroup emotions and intergroup forgiveness would be stronger than the relationship between general evaluation (outgroup attitude) and forgiveness. Results showed that anger-related intergroup emotions predicted forgiveness. The significantly worse fit of the model with equality constraints imposed confirmed that anger predicted more variance in intergroup forgiveness than did outgroup attitudes. The results thus favored the ability of emotion (specifically anger) to predict intergroup forgiveness over that of outgroup attitude, and demonstrated the inverse relationship between the specific emotion of anger and intergroup forgiveness. Thus, it may not be enough to like the outgroup in order to forgive them. Factors beyond simply having positive outgroup attitudes need to be addressed in order to achieve forgiveness.

Intergroup forgiveness plays an integral part in the achievements of organizations such as the Northern Ireland Victims Commission. However, despite the importance of intergroup forgiveness for areas of conflict, empirical research on this construct is lacking. Results suggest that the promotion of intergroup forgiveness in conflict societies should involve certain psychological processes. The reduction of the specific intergroup emotion of anger should be targeted in particular; in addition, interventions should aim to decrease infra-humanization of the outgroup. The data, moreover, suggest contact to be one intervention that may help to decrease anger toward the outgroup for perceived past offenses and enhance more positive attitudes toward them.

Of course, these implications must be considered alongside the cross-sectional nature of our research, which makes it difficult to establish causality definitively in our model. However, previous research and theory suggest the causal order we proposed, and the ability of SEM to test complex a priori predictions and alternative models allows for some optimism about its assumed causal directions. Moreover, this research was also conducted in the context of real intergroup conflict, rather than with manipulated variables in a laboratory, as we aimed to investigate people's real-life experiences of intergroup emotions and contact in context. To find significant effects under these circumstances suggests that we are dealing with robust and important empirical relationships. However, we acknowledge that the reverse causal model may also, perhaps even simultaneously, hold true; intergroup forgiveness may also lead to decreased anger, decreased infra-humanization, and more positive outgroup attitudes, which, in turn, lead to increased intergroup contact. (This model is however statistically equivalent to the proposed model, and thus cannot be tested in comparison.) 
The results of this study established predictors of forgiveness for the outgroup. By understanding the antecedents of intergroup forgiveness, it may be possible to create theoretically driven interventions to increase forgiveness in an area of conflict. Focus groups with Northern Irish citizens have shown a strong antipathy to imposing forgiveness upon victims of intergroup violence. To promote intergroup forgiveness, therefore, it is perhaps more important to look at the established predictors of intergroup forgiveness. Interventions should aim to include elements of targeting the specific emotion of anger as well as emphasizing the 'humanity' of members of the outgroup. John Hume, who shared the Nobel Peace Prize for his role in furthering the peace process in Northern Ireland, emphasized the vital role 'humanizing the other' has played. 'We have to realise', he said, 'that our common humanity transcends our differences'. As part of the healing process, Hume advocated programs that encourage Catholics and Protestants to live, work, and be educated together. 'The real border is not between north and south', he said, 'but in the minds and hearts of our people' (Dozier, 2002, p. 291).

For post-conflict societies such as Northern Ireland, an understanding of the psychological factors that promote intergroup forgiveness is imperative, and the consequences of a history of intergroup violence must be addressed. Opportunities for people to deal with their grievances and anger-which clearly hold the potential to derail the peace process-must be provided. Deep engagement can help people see the humanity of the other by addressing prior hurts, pain, and violence that the groups have inflicted upon each other (Staub, 2001). A more complete understanding of intergroup forgiveness will leave us better prepared to take on the challenges involved in the process of reconciliation in post-conflict societies.

\section{References}

Allport, G. W. (1954). The nature of prejudice. Oxford, UK: Addison-Wesley.
Anderson, J. C., \& Gerbing, D. W. (1988). Structural equation modeling in practice: A review and recommended two-step approach. Psychological Bulletin, 103, 411-423.

Arbuckle, J. L. (2004). Amos 5.0 [Computer Software]: SmallWaters Corp.

Baumeister, R., Exline, J. J., \& Sommer, K. L. (1998). The victim role, grudge theory, and two dimensions of forgiveness. In J. E. L. Worthington (Ed.), Dimensions of forgiveness: Psychology research and theoretical perspectives. Philadelphia: Templeton.

Brown, R., Maras, P., Masser, B., Vivian, J., \& Hewstone, M. (2001). Life on the ocean wave: Testing some intergroup hypotheses in a naturalistic setting. Group Processes E Intergroup Relations, 4, 81-97.

Cairns, E., \& Darby, J. (1998). The conflict in Northern Ireland: Causes, consequences, and controls. American Psychologist, 53, 754-760.

Cairns, E., Tam, T., Hewstone, M., \& Niens, U. (2005). Intergroup forgiveness and intergroup conflict: Northern Ireland, a case study. In J. Everett L. Worthington (Ed.), Handbook of forgiveness. New York: Brunner-Routledge.

Devos, T., Silver, L. A., Mackie, D. M., \& Smith, E. R. (2002). Experiencing intergroup emotions. In D. M. Mackie \& E. R. Smith (Eds.), From prejudice to intergroup emotions (pp. 111-134). New York: Taylor \& Francis, Inc.

Dovidio, J. F., Gaertner, S. L., Esses, V. M., \& Brewer, M. B. (2003). Social conflict, harmony, and integration. New York: Wiley.

Dozier, R. W. (2002). Why we hate: Understanding, curbing, and eliminating hate in ourselves and our world. Chicago: Contemporary Books.

Ekman, P. (1992). Are there basic emotions? Psychological Review, 99, 550-553.

Enright, R. D., and Coyle, C. T. (1998). Researching the process model of forgiveness within psychological interventions. In J. E. L. Worthington (Ed.), Dimensions of forgiveness: Psychology research and theoretical perspectives. Philadelphia: Templeton.

Enright, R. D., Freedman, S., \& Rique, J. (1998). The psychology of interpersonal forgiveness. In R. D. Enright \& J. North (Eds.), Exploring forgiveness (pp. 46-62). Madison, WI: University of Wisconsin Press.

Freedman, S., \& Enright, R. D. (1996). Forgiveness as an intervention goal with incest survivors. Journal of Consulting and Clinical Psychology, 64, 983-992. 
Frijda, N. H. (1986). The emotions. Cambridge University Press.

Greenwald, A. G., McGhee, D. E., \& Schwartz, J. L. K. (1998). Measuring individual differences in implicit cognition: The implicit association test. Journal of Personality and Social Psychology, 74, 1464-1480.

Harber, K. D., \& Wenberg, K. E. (2005). Emotional disclosure and closeness toward offenders. Personality and Social Psychology Bulletin, 31, 734-746.

Hargie, O., \& Dickson, D. (2003). Researching the troubles: Social science perspectives on the Northern Ireland conflict. Edinburgh: Mainstream.

Hewstone, M., Cairns, E., Kenworthy, J., Hughes, J., Tausch, N., Voci, A. et al. (in press). Stepping stones to reconciliation in Northern Ireland: Intergroup contact, forgiveness and trust. In A. Nadler, T. Malloy, \& J. D. Fisher (Eds.), The social psychology of inter-group reconciliation. New York: Oxford University Press.

Hewstone, M., Cairns, E., Voci, A., Hamberger, J. \& Niens, U. (2006). Intergroup contact, forgiveness, and experience of 'The Troubles' in Northern Ireland. Journal of Social Issues, 62, 99-120.

Hewstone, M., Cairns, E., Voci, A., McLernon, F., Niens, U., \& Noor, M. (2004). Intergroup forgiveness and guilt in Northern Ireland: Social psychological dimensions of 'The Troubles'. In N. R. Branscombe \& B. Doosje (Eds.), Collective guilt: International perspectives (pp. 193-215). New York: Cambridge University Press.

Kachadourian, L. K., Fincham, F., \& Davila, J. (2005). Attitudinal ambivalence, rumination, and forgiveness of partner transgressions in marriage. Personality and Social Psychology Bulletin, 31, 334-342.

Leyens, J. P., Paladino, P. M., Rodriguez-Torres, R., Vaes, J., Demoulin, S., Rodriguez-Perez, A. et al. (2000). The emotional side of prejudice: The attribution of secondary emotions to ingroups and outgroups. Personality and Social Psychology Review, 4, 186-197.

Leyens, J. P., Rodriguez-Perez, A., RodriguezTorres, R., Gaunt, R., Paladino, M. P., Vaes, J., \& Demoulin, S. (2001). Psychological essentialism and the differential attribution of uniquely human emotions to ingroups and outgroups. European Journal of Social Psychology, 31, 395-411.

Little, T. D., Cunningham, W. A., Shahar, G., \& Widaman, K. F. (2002). To parcel or not to parcel: Exploring the question, weighing the merits. Structural Equation Modeling, 9, 151-173.
MacCallum, R. C., \& Austin, J. T. (2000).

Applications of structural equation modeling in psychological research. Annual Review of Psychology, 51, 201-226.

Mackie, D. M., Devos, T., \& Smith, E. R. (2000). Intergroup emotions: Explaining offensive action tendencies in an intergroup context. Journal of Personality and Social Psychology, 79, 602-616.

Mackie, D. M., \& Smith, E. R. (1998). Intergroup relations: Insights from a theoretically integrative approach. Psychological Review, 105, 499-529.

Mackie, D. M., \& Smith, E. R. (2002). Intergroup emotions and the social self: Prejudice reconceptualized as differentiated reactions to outgroups. In J. Forgas (Ed.), The Social Self.

McCullough, M. E. (2001). Forgiveness: Who does it and how do they do it? Current Directions in Psychological Science, 10, 194-196.

McCullough, M. E., Bellah, C. G., Kilpatrick, S. D., and Johnson, J. L. (2001). Vengefulness: Relationships with forgiveness, rumination, well-being and the big five. Personality and Social Psychology Bulletin, 27, 601-610.

McCullough, M. E., Pargament, K. I., \& Thoresen, C. E. (2000). The psychology of forgiveness: History, conceptual issues, and overview. In M. E. McCullough, K. I. Pargament \& C. E. Thoresen (Eds.), Forgiveness: Theory, research, and practice (pp. 1-14). New York: Guilford.

McCullough, M. E., Worthington, E. L., Jr., \& Rachal, K. C. (1997). Interpersonal forgiving in close relationships. Journal of Personality and Social Psychology, 73, 321-336.

McLernon, F., Cairns, E., \& Hewstone, M. (2002). Views on forgiveness in Northern Ireland. Peace Review: A Journal of Social Justice, 14, 285-290.

Miller, D. A., Smith, E. R., \& Mackie, D. M. (2004). Effects of intergroup contact and political predispositions on prejudice: Role of intergroup emotions. Group Processes $\mathcal{E}^{2}$ Intergroup Relations, 7, 221-237.

Nadler, A. (2002). Post-resolution processes: Instrumental and socioemotional routes to reconciliation. In G. Salomon \& B. Nevo (Eds.), Peace education: The concept, principles, and practices around the world (pp. 127-142). Mahwah, NJ: Lawrence Erlbaum.

Nadler, A. (2001). Post-resolution processes: Instrumental and socioemotional routes to reconciliation. In G. Salomon \& B. Nevo (Eds.), Peace education: The concept, principles, and practices 
around the world (pp. 127-142). Mahwah, NJ:

Lawrence Erlbaum Associates.

Paladino, M. P., Leyens, J. P., Rodriguez, R., Rodriguez, A., Gaunt, R., \& Demoulin, S. (2002). Differential association of uniquely and non uniquely human emotions with the ingroup \& the outgroup. Group Processes and Intergroup Relations, 5, 105-117.

Paolini, S., Hewstone, M., Cairns, E., \& Voci, A. (2004). Effects of direct and indirect cross-group friendships on judgments of Catholics and Protestants in Northern Ireland: The mediating role of an anxiety-reduction mechanism. Personality and Social Psychology Bulletin, 30, 770-786.

Pettigrew, T. F. (1997). Generalized intergroup contact effects on prejudice. Personality and Social Psychology Bulletin, 23, 173-185.

Pettigrew, T. F., \& Tropp, L. (2006). A meta-analytic test of intergroup contact theory. Journal of Personality and Social Psychology, 90, 751-783.

Rye, M. S., \& Pargament, K. I. (2002). Forgiveness and romantic relationships in college: Can it heal the wounded heart? Journal of Clinical Psychology, 58, 419-441.

Smith, E. R. (1993). Social identity and social emotions: Toward new conceptualizations of prejudice. In Affect, cognition, and stereotyping. San Diego, CA: Academic Press.

Smyth, M., \& Hamilton, J. (2003). The human costs of the troubles. In O. Hargie \& D. Dickson (Eds.), Researching the troubles: Social science perspectives on the Northern Ireland conflict (pp. 15-36). Edinburgh, UK: Mainstream.

Staub, E. (2001). Individual and group identities in genocide and mass killing. In D. Richard, L. Jussim, \& D. Wilder (Eds.), Social identity, intergroup conflict, and conflict reduction (pp. 159-184). London: Oxford University Press.

Tam, T., Hewstone, M., Kenworthy, J., Voci, A., Cairns, E., \& Van Dick, R. (2006). The role of intergroup emotions and empathy in contact between Catholics and Protestants in Northern Ireland. Manuscript under review.

Tutu, D. (1999). No future without forgiveness. London: Random House.

Voci, A., \& Hewstone, M. (2003). Intergroup contact and prejudice toward immigrants in Italy: The mediational role of anxiety and the moderational role of group salience. Group Processes E Intergroup Relations, 6, 37-54.

Wegner, D. M., \& Wenzlaff, R. M. (1996). Mental control. In E. T. Higgins \& A. W. Kruglanski
(Eds.), Social psychology: Handbook of basic principles (pp. 466-492). New York: Guilford.

Wohl, M. J. A., \& Branscombe, N. R. (2005). Forgiveness and collective guilt assignment to historical perpetrator groups depend on level of social category inclusiveness. Journal of Personality and Social Psychology, 88, 288-303.

Worthington, E. L., Jr. (1998). The pyramid model of forgiveness: Some interdisciplinary speculations about unforgiveness and the promotion of forgiveness. In E.L. Worthington Jr. (Ed.), Dimensions of forgiveness: Psychological research and theological perspectives (pp. 107-137). Philadelphia: Templeton Foundation.

Wright, S. C., Aron, A., McLaughlin-Volpe, T., \& Ropp, S. A. (1997). The extended contact effect: Knowledge of cross-group friendships and prejudice. Journal of Personality and Social Psychology, 73, 73-90.

Zajonc, R. B. (1980). Feeling and thinking: Preferences need no inferences. American Psychologist, 35, 151-171.

Zechmeister, J. S., \& Romero, C. (2002). Victim and offender accounts of interpersonal conflict: Autobiographical narratives of forgiveness and unforgiveness. Journal of Personality and Social Psychology, 82.

Paper received 1 December 2005; revised version accepted 31 July 2006.

\section{Biographical notes}

TANIA TAM earned her PhD in the psychology of intergroup conflict from the University of Oxford, UK, in 2005, and is currently a social statistician and researcher at the Legal Services Research Centre in London, England. Her research currently focuses on policies related to civil and judiciable problems, including discrimination, debt, and contact. Her research interests also include intergroup forgiveness, trust, empathy, and positive psychology.

MILES HEWSTONE is professor of social psychology and Fellow of New College, Oxford University. He has published widely on the topics of attribution theory, social cognition, stereotyping, and intergroup relations. His current research focuses on the reduction of intergroup conflict. $\mathrm{He}$ is co-founding editor of the European Review of Social Psychology, and a former editor of the British Journal of Social Psychology. He is a 
Fellow of the British Academy and an Honorary Fellow of the British Psychological Society. He was the recipient of the Kurt Lewin Award, for Distinguished Research Achievement, from the European Association for Experimental Social Psychology in 2005.

ED CAIRNS is professor of psychology at the University of Ulster in Northern Ireland. He has spent the last thirty years studying the psychological aspects of political violence in relation to the conflict in Northern Ireland. During this time he has been a visiting scholar at the universities of Florida, Cape Town and Melbourne. He is a Fellow of the British Psychological society and of the American Psychological Association (APA) and past president of the Division of Peace Psychology of the APA.

NICOLE TAUSCH is a postdoctoral research associate at the University of Oxford, UK. Her main research interests lie broadly in the areas of stereotyping, prejudice, and intergroup conflict. Her current research focuses on how people deal with stereotype-inconsistent information, the potential disconfirmability of personality traits and cross-community contact, threat, and prejudice in Northern Ireland and India.

GREG MAIO is a professor at Cardiff University, UK. He conducts research on several topics in social psychology, including prejudice, attitude structure and function, and emotional processes.

JARED KENWORTHY is currently an assistant professor of psychology at the University of Texas at Arlington. His research interests are in intergroup relations, intergroup contact and prejudice reduction, social identity processes, and social categorization. He teaches social psychology, human relations, and group processes at the undergraduate and graduate levels. 